\title{
AUFHOLJAGD
}

Liebe Leserin, lieber Leser,

im Gegensatz zum Pkw-Bereich wurde bei Offhighway-Fahrzeugen erst seit 2011 mit der Stufe III B die erste serienmäßige Abgasnachbehandlungstechnik in mobilen Maschinen notwendig. Ab diesem Zeitpunkt forcierte der Gesetzgeber allerdings sehr stark die Begrenzung der Abgasgrenzwerte auch abseits der Straße. So sind seit Oktober nun die Abgasgrenzwerte gemäß Stufe IV für alle Motorleistungen von 56 bis $560 \mathrm{~kW}$ in Kraft. Diese schnelle Forcierung brachte viele Hersteller an den Rand ihrer Möglichkeiten. Als Ergebnis wurden andere interessante Forschungs- und Entwicklungsthemen vernachlässigt.

Bezüglich der Partikelanzahl herrschen im Offhighway-Bereich bis dato keine Vorgaben. Eine Grenzzahl für die Partikelanzahl wird allerdings mit der ab Ende dieses Jahrzehnts geplanten Stufe V erwartet. Nachteil hierbei ist allerdings, dass durch den Einsatz von Partikelfiltern der Kraftstoffverbrauch und somit die $\mathrm{CO}_{2}$-Erzeugung erhöht wird, da der Partikelfilter einen höheren Verbrauch verursacht. Dies ist aber gemäß Vorschriften kein Problem, da Grenzwerte für $\mathrm{CO}_{2}$ auch weiterhin nicht vorgesehen sind.

Gerade aber die Reduzierung von $\mathrm{CO}_{2}$ würde Sinn machen, da mit dessen Reduzierung gleichzeitig eine Effizienzsteigerung und somit eine Gesamtsys- tembetrachtung einhergehen müsste. Dies wäre bezüglich Ressourcenverknappung und Umweltproblemen eine sinnvolle Maßnahme. Aber auch die europäischen Land- und Baumaschinenhersteller würden hiervon profitieren, da beispielsweise in Asien europäische Produkte wegen ihrer robusten Technik und Effizienz und nicht wegen der ausgefeilten Abgasnachbehandlungssysteme nachgefragt werden. Eine Steigerung der Effizienz würde somit weitere Wettbewerbsvorteile schaffen!

Ihr

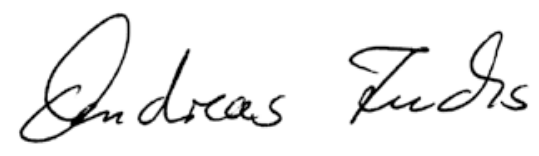

ANDREAS FUCHS, Chefkorrespondent Hochheim, 8. Oktober 2014

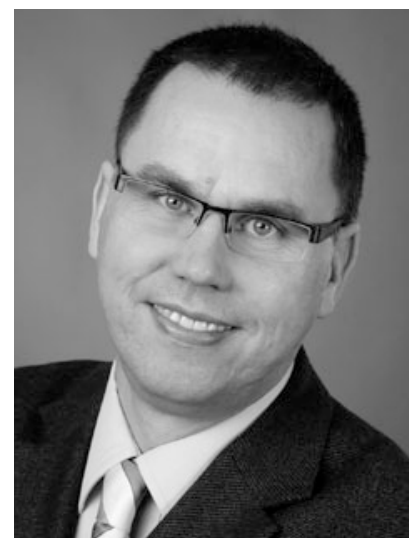

\section{CATCHING UP}

Dear Reader,

Unlike in the passenger car sector, exhaust aftertreatment in the off-highway sector did not become mandatory as standard equipment in mobile machines until 2011 with the introduction of Stage III B. From that time onwards, however, legislation began to impose very strict emissions standards also for off-highway vehicles. Since October, the Stage IV emissions standards have been in force for all engine outputs from 56 to $560 \mathrm{~kW}$. This rapid tightening took many manufacturers to the limits of their possibilities. As a result, other interesting research and development topics were neglected.

As far as the particle number is concerned, no limit has been set for the off-highway sector to date. However, a limit value for the particle number is expected to come into force with Stage $V$, which is planned for the end of this decade. The disadvantage of this, however, is that the use of particulate filters will increase fuel consumption and therefore the generation of $\mathrm{CO}_{2}$, as the particulate filter itself causes a higher fuel consumption. But this is not a problem with regard to the legislation, as there are still no plans to introduce limit values for $\mathrm{CO}_{2}$.

But a reduction in $\mathrm{CO}_{2}$ in particular would make sense, as this would also involve an increase in efficiency. That would be a sensible measure against a background of depleted resources and environmental problems. And what is more, European manufacturers of agricultural and construction machines would also benefit, as European products are in demand, for example in Asia, because of their robust engineering and efficiency and not because of their sophisticated exhaust aftertreatment systems. Improving efficiency would therefore create further competitive advantages!

Best regards, 